\title{
Methanobacterium kanagiense sp. nov., a hydrogenotrophic methanogen, isolated from rice-field soil
}

Correspondence

Akio Tonouchi

symbio@cc.hirosaki-u.ac.jp

\author{
Koji Kitamura, ${ }^{1,2}$ Takashi Fujita, ${ }^{2}$ Shinji Akada $^{2}$ and Akio Tonouchi ${ }^{2}$ \\ ${ }^{1}$ The United Graduate School of Agricultural Sciences, Iwate University, 3-18-8, Ueda, Morioka, \\ Iwate 020-8550, Japan \\ ${ }^{2}$ Faculty of Agriculture and Life Science, Hirosaki University, 3 Bunkyo-cho, Hirosaki, \\ Aomori 036-8561, Japan
}

\begin{abstract}
A pure culture of an obligately anaerobic, hydrogenotrophic, methanogenic archaeon, designated strain $169^{\top}$, which grows with hydrogen and carbon dioxide as the sole energy and carbon sources, was isolated from an anaerobic propionate-oxidizing enrichment culture originally obtained as an inoculant from rice-field soil in Japan. Cells of strain $169^{\top}$ were non-motile, Gram-reaction-variable and rod-shaped or slightly curved rods with rounded ends $\left(1.6-5.0 \times 0.35-0.5 \mu \mathrm{m}\right.$ ). Strain $169^{\top}$ had fimbriae at both ends of the cell (up to $\sim 10$ per cell) but did not possess flagella. Ultrathin sections showed a single-layered, electron-dense cell wall about $6 \mathrm{~nm}$ thick, which is typical of Gram-positive bacteria. Growth was observed at $15{ }^{\circ} \mathrm{C}-45^{\circ} \mathrm{C}$ (optimum $40{ }^{\circ} \mathrm{C}$ ), at $\mathrm{pH} 6.5-9.6$ (optimum pH 7.5-8.5) and in $0-70 \mathrm{~g} \mathrm{NaCl} \mathrm{I}^{-1}$ $\left(0-1.2 \mathrm{M}\right.$ ) (optimum $5 \mathrm{~g} \mathrm{NaCl}^{-1} ; 0.086 \mathrm{M}$ ). Strain $169^{\top}$ utilized only hydrogen and carbon dioxide as energy and carbon sources. The DNA G $+\mathrm{C}$ content was $39.3 \mathrm{~mol} \%$. The results of $16 \mathrm{~S}$ rRNA gene sequence analysis indicated that strain $169^{\top}$ was most closely related to Methanobacterium subterraneum DSM $11074^{\top}$ (96.8\% sequence similarity) and Methanobacterium formicicum DSM $1535^{\top}$ (96.4\%). On the basis of its morphological, physiological and phylogenetic characteristics, strain $169^{\top}\left(=\mathrm{DSM} 22026^{\top}=\mathrm{JCM} 15797^{\top}\right)$ represents a novel species of the genus Methanobacterium, for which the name Methanobacterium kanagiense sp. nov. is proposed.
\end{abstract}

Methane is one of the greenhouse gases and flooded rice fields are estimated to be a significant source of atmospheric methane (Prinn, 1994; Cicerone \& Oremland, 1988; Galchenko et al., 1989). Methane is produced by methanogenic archaea, which play an important role in anaerobic ecosystems, such as flooded rice field soils, by performing the final step in the anaerobic decomposition of organic matter. Methanogenic bacteria have been isolated from various natural anoxic environments (Boone et al., 1993; Garcia, 1990; Mah \& Smith, 1981). Many strains have been isolated from rice field soils, including members of the genera Methanobacterium, Methanobrevibacter, Methanoculleus, Methanosaeta, Methanosarcina and Methanocella (Asakawa et al., 1993, 1995; Fetzer et al., 1993; Großkopf et al., 1998; Joulian et al., 1998; Raimbault, 1981; Rajagopal et al., 1988; Sakai et al.,

Abbreviations: Pei, pseudomurein endoisopeptidase; rPeiW, recombinant pseudomurein endoisopeptidase.

The DDBJ/EMBL/GenBank accession numbers for the 16S rRNA and $m c r A$ gene sequences of strain $169^{\top}$ are AB368917 and AB551869, respectively.
2008). In anoxic rice-field soils, hydrogen and acetate are the main methanogenic substrates (Conrad et al., 1989a; Takai, 1970) and are produced as a result of fermentative metabolism or the activity of syntrophic associations between volatile fatty acid (acetate, propionate or butyrate)-oxidizing, hydrogen-producing bacteria and hydrogenotrophic methanogenic archaea (Dong \& Stams, 1995; Schink, 1992; Stams, 1994). A high proportion (95\%$97 \%$ ) of the hydrogenotrophic methanogenesis in ricefield soils occurs in syntrophic associations (Conrad et al., 1989b); however, the details of natural anoxic habitats remain, largely, to be determined. To understand the ecology of methanogenic archaea as hydrogen scavengers in anoxic environments, characterization and identification of methanogenic isolates with syntrophic associations are important. In this study, we describe the isolation and characterization of a methanogenic archaeon, designated strain $169^{\mathrm{T}}$, obtained from an anaerobic, propionateoxidizing enrichment culture derived from rice-field soil as an inoculant. Strain $169^{\mathrm{T}}$, which uses only hydrogen and carbon dioxide as methanogenic substrates, is physiologically and phylogenetically distinct from other members of 
the genus Methanobacterium. Therefore, it is proposed that strain $169^{\mathrm{T}}$ represents a novel species of the genus Methanobacterium.

The sampling site was a rice-field plot at Kanagi Farm, part of the Teaching and Research Center for Bio-coexistence, University Farm, Faculty of Agriculture and Life Science, Hirosaki University. Sampling was performed in August 2002.

All procedures were conducted under anaerobic conditions. The basal medium used for routine cultivation was prepared as described previously (Widdel \& Pfennig, 1981), except that sodium sulphate was omitted. It contained $\left(\mathrm{l}^{-1}\right): 0.2 \mathrm{~g}$ $\mathrm{KH}_{2} \mathrm{PO}_{4}, 0.25 \mathrm{~g} \mathrm{NH}_{4} \mathrm{Cl}, 1.0 \mathrm{~g} \mathrm{NaCl}, 0.4 \mathrm{~g} \mathrm{MgCl}_{2} .6 \mathrm{H}_{2} \mathrm{O}$, $0.5 \mathrm{~g} \mathrm{KCl}, 0.15 \mathrm{~g} \mathrm{CaCl}_{2} \cdot 2 \mathrm{H}_{2} \mathrm{O}, 1 \mathrm{ml}$ trace element solution SL-7 (Widdel \& Pfennig, 1981), $0.4 \mathrm{mg}$ resazurin, $2.52 \mathrm{~g} \mathrm{NaHCO}_{3}, 1 \mathrm{ml} \mathrm{Na} \mathrm{SeO}_{3} .5 \mathrm{H}_{2} \mathrm{O}\left(0.3 \mathrm{mg} \mathrm{l} \mathrm{l}^{-1}\right), 1 \mathrm{ml}$ $\mathrm{Na}_{2} \mathrm{WO}_{4} \cdot 2 \mathrm{H}_{2} \mathrm{O}\left(0.4 \mathrm{mg} \mathrm{l}^{-1}\right), 2 \mathrm{ml} p$-aminobenzoic acid (40 $\left.\mathrm{mg} \mathrm{l}^{-1}\right), 2 \mathrm{ml} \mathrm{D}-(+)$-biotin $\left(10 \mathrm{mg} \mathrm{l}^{-1}\right), 2 \mathrm{ml}$ thiamine chloride $\left(100 \mathrm{mg} \mathrm{l}^{-1}\right)$ and $1 \mathrm{ml}$ vitamin $B_{12}\left(50 \mathrm{mg} \mathrm{l}^{-1}\right)$. The $\mathrm{pH}$ was adjusted to $7.2-7.5$ by addition of an anaerobic, sterile solution of $2 \mathrm{M} \mathrm{HCl}$.

For enrichment of the propionate-degrading consortia present in the soil of a rice field, $5 \mathrm{~g}$ samples of soil were inoculated into $100 \mathrm{ml}$ of basal medium in $125 \mathrm{ml}$ serum bottles containing $20 \mathrm{mM}$ sodium propionate followed by static incubation at $30{ }^{\circ} \mathrm{C}$ in an oxygen-free nitrogen atmosphere. After the complete consumption of propionate and acetate, which transiently accumulated as an intermediate during the methanogenic degradation of propionate, $1 \mathrm{ml}$ of the culture, including sediment, was transferred into fresh medium and incubated as before. After seven transfers using the same medium, a hydrogenotrophic methanogen was isolated by repeated application of Hungate's roll tube technique (Hungate, 1969) using hydrogen/carbon dioxide $(80: 20,2 \mathrm{~atm})$ as a methanogenic substrate, which was also used for subsequent cultivation of the isolate, unless stated otherwise.

Levels of propionate and acetate were determined by GC (Shimadzu model GC-8A) using a Porapak N column (Waters) connected to a flame-ionization detector. The oven temperature was $180{ }^{\circ} \mathrm{C}$ and nitrogen was used as the carrier gas. Levels of methane and hydrogen were determined by GC using a WG-100 column (GL Science) connected to a thermal conductivity detector. The oven temperature was $60{ }^{\circ} \mathrm{C}$ and argon was used as the carrier gas.

Phase-contrast and epifluorescence microscopy were carried out with an Olympus model BX50 photomicroscope. Autofluorescence of the cells was observed with a V (BP400-410) excitation filter. Gram staining was carried out according to the method of Bartholomew \& Mittwer (1952). For electron microscopy, cells were collected from late-exponential-phase cultures by centrifugation at $7000 \mathrm{~g}$ for $10 \mathrm{~min}$ at $4{ }^{\circ} \mathrm{C}$ and washed twice in sterilized doubledistilled water. For transmission electron microscopy, cells were resuspended in double-distilled water and negatively stained with $0.5 \%$ phosphotungstic acid $(\mathrm{pH} \mathrm{7)}$. For ultrathin sections, cells were fixed in $2.5 \%$ glutaraldehyde for $18 \mathrm{~h}$ and post-fixed in $1 \%$ osmium tetroxide for $1.5 \mathrm{~h}$ in Kellenberger buffer (pH 6) (Kellenberger et al., 1958) at $4{ }^{\circ} \mathrm{C}$. The fixed cells were embedded in Spurr's resin and sectioned with glass knives on an LKB 2188-NOVA ultramicrotome. Sections were stained with uranyl acetate and post-stained with lead citrate. All of the specimens for transmission electron microscopy were examined with a JEOL model JEM-2000 EX electron microscope operated at $80 \mathrm{kV}$.

Genomic DNA of strain $169^{\mathrm{T}}$ was extracted from pseudomurein endoisopeptidase (Pei)-treated cells according to the method of Nakamura et al. (2006). Pei from Methanothermobacter wolfeii was kindly provided by Dr Nakamura (Gifu University, Japan) as a recombinant enzyme (rPeiW) expressed in Escherichia coli $(0.5 \mathrm{mg}$ rPeiW $\mathrm{ml}^{-1} \mathrm{H}$ buffer: $50 \mathrm{mM}$ HEPES, $\mathrm{pH} 7.0 ; 5 \mathrm{mM}$ dithiothreitol; $20.8 \mathrm{mM} \mathrm{Na} \mathrm{Na}_{2} \mathrm{~S}$ ). Late-exponential-phase cells of strain $169^{\mathrm{T}}$ were harvested by centrifugation at 7000 r.p.m. for $10 \mathrm{~min}$ at $4{ }^{\circ} \mathrm{C}$. The cells were washed twice with $\mathrm{H}$ buffer and resuspended in $\mathrm{H}$ buffer to give a cell density of approximately $10^{10}$ c.f.u. $\mathrm{ml}^{-1}$. An aliquot of $1 \mathrm{ml}$ of the cell suspension was transferred into a $5 \mathrm{ml}$ vial under a stream of oxygen-free nitrogen gas and the vial was sealed with a butyl-rubber stopper and closed with an aluminium cap. The vial was incubated at $70{ }^{\circ} \mathrm{C}$ for $10 \mathrm{~min}$ in a reciprocating water bath at 150 r.p.m., followed by the addition of $0.1 \mathrm{ml} \mathrm{rPeiW}$ and an additional incubation period of $1 \mathrm{~h}$ at $70{ }^{\circ} \mathrm{C}$ under the same operating conditions. The genomic DNA was extracted and purified by phenol/chloroform extraction followed by RNaseA treatment, a second phenol/chloroform extraction and ethanol precipitation. The dried DNA pellet was then resuspended in sterile water. Aliquots of $10 \mu \mathrm{l}$ of the purified DNA $\left(1 \mu \mathrm{g} \mu \mathrm{l}^{-1}\right)$ were hydrolysed with 0.02 units of P1 nuclease (Yamasa Shoyu) to yield mononucleotides. The DNA G $+\mathrm{C}$ content was determined by reversed-phase HPLC using a Shimadzu model LC-10ADVP system. Separation of the mononucleotides was performed at $40{ }^{\circ} \mathrm{C}$ and at a flow rate of $1.5 \mathrm{ml} \mathrm{m^{-1 }}$ using a YMC-Pack ODS-AQ column $(150 \times 6.0 \mathrm{~mm}, 5 \mu \mathrm{m}$ particle size, $12 \mathrm{~nm}$ pore; YMC) and $10 \mathrm{mM}$ phosphate buffer $(\mathrm{pH} 3.8)$ as the mobile phase. Each deoxyribonucleotide was detected by measuring $A_{270}$. An equimolar mixture of four deoxynucleotides was used as a control.

The following substrates were tested for utilization $(20 \mathrm{mM}$ unless stated): $\mathrm{H}_{2} / \mathrm{CO}_{2}$ (2 atm; 80:20, v/v), methanol, formate, acetate, methylamine, dimethylamine, trimethylamine, ethanol, 1-propanol, 2-propanol, 1-butanol, 2-butanol, 3-methyl-1-butanol, pyruvate, 1-pentanol, 2pentanol and cyclopentanol. Substrate utilization was determined by the measurement of methane levels and the observation of the growth in comparison with a blank control. 
Growth of strain $169^{\mathrm{T}}$ was determined at $4-60{ }^{\circ} \mathrm{C}$ and in 0 $15 \%(\mathrm{w} / \mathrm{v}) \mathrm{NaCl}$. Salinity and $\mathrm{pH}$ tests were performed at $40{ }^{\circ} \mathrm{C}$. As no growth was observed at $\mathrm{NaCl}$ concentrations above $8 \%$, and growth at $7 \%$ was too slow to calculate over the test period of 4 weeks, the optimum concentration for growth was determined in $0,0.1,0.25,0.5,1,3$, and $5 \%(\mathrm{w} / \mathrm{v}) \mathrm{NaCl}$. Media with different $\mathrm{pH}$ values were prepared by varying the concentration of $\mathrm{NaHCO}_{3}$ or $\mathrm{Na}_{2} \mathrm{CO}_{3}$ and the $\mathrm{pH}$ was adjusted using sterile $5 \% \mathrm{Na}_{2} \mathrm{CO}_{3}$ or $2 \mathrm{M} \mathrm{HCl}$ solution. Growth at different $\mathrm{pH}$ values, temperatures and $\mathrm{NaCl}$ concentrations was monitored by measuring $\mathrm{OD}_{420}$ over time using a photoelectric colorimeter (Mini Photo 10; Sanshin). The requirement of vitamins for growth was tested by transferring cultures into vitamin-depleted media containing possible growth factors and comparing these with control cultures that contained vitamins or did not contain any vitamins. Methane production was monitored during incubation at $40{ }^{\circ} \mathrm{C}$ for 10 days and evaluated by comparison to the controls.

All physiological experiments were performed in triplicate except for substrate utilization, salinity and vitamin requirement tests, which were performed in duplicate.

The effects of antibiotics on growth were determined using the following compounds: ampicillin, chloramphenicol, streptomycin, nalidixic acid, neomycin, bacitracin, vancomycin and penicillin. The susceptibility of strain $169^{\mathrm{T}}$ to these antibiotics was determined using media containing one of the above antibiotics at concentrations of 100, 500, 1000 and $2000 \mathrm{mg} \mathrm{l}^{-1}$. Duplicate cultures were incubated for 2 weeks and the effects of the antibiotics were determined by comparing the growth rates with control cultures containing no antibiotics. Growth rate was determined by monitoring $\mathrm{OD}_{420}$.

Primers ArckF (5'-TTGATCCTGSCGGAGGCYACYGCT$\left.3^{\prime}\right)$ and ArckR (5'-CCAGCCGCAGRTTCCCCTACGGC$3^{\prime}$ ) (Oyaizu \& Hiraishi, 1999) were used to amplify the partial 16S rRNA gene of strain $169^{\mathrm{T}}$. Aliquots $(1 \mu \mathrm{l})$ of cell suspension were added to a mixture of $1.25 \mathrm{U}$ Taq DNA polymerase (HotStarTaq; Qiagen), $10 \times$ PCR buffer (with $15 \mathrm{mM} \mathrm{MgCl}$; Qiagen), $0.2 \mathrm{mM} \mathrm{dNTP}$, the two primers $(0.5 \mu \mathrm{M})$ and double-distilled water to a final volume of $50 \mu \mathrm{l}$. The thermal program included an initial denaturation step $\left(95^{\circ} \mathrm{C}, 15 \mathrm{~min}\right)$ followed by 35 cycles of denaturation $\left(95{ }^{\circ} \mathrm{C}, 60 \mathrm{~s}\right)$, annealing $\left(55^{\circ} \mathrm{C}, 60 \mathrm{~s}\right)$ and extension $\left(72{ }^{\circ} \mathrm{C}, 90 \mathrm{~s}\right)$ with a final extension step $\left(72{ }^{\circ} \mathrm{C}\right.$ for $6 \mathrm{~min})$. The amplified products were cloned into pUC19 and sequenced with a GeneRapid DNA Sequencer (Amersham Pharmacia Biotech). A partial fragment of the $m c r A$ gene of strain $169^{\mathrm{T}}$ was amplified using the primers mcrA-f $\quad$ (5'-GGTGGTGTMGGATTCACACARTAYGCWACAGC- $\left.3^{\prime}\right)$ and mcrA-r (5'-TTCATTGCRTAGTTWGGRTAGTT-3') (Luton et al., 2002). The reaction mixture consisted of $10 \mu \mathrm{l}$ GoTaq Green Master Mix (Promega), each primer at $1 \mu \mathrm{M}, 1 \mu \mathrm{l}$ of the cell suspension as template and sterilized water to a final volume of $20 \mu \mathrm{l}$. PCR was performed with a denaturation step at $95{ }^{\circ} \mathrm{C}$ for $2 \mathrm{~min}$ followed by 35 cycles of $95{ }^{\circ} \mathrm{C}$ for $30 \mathrm{~s}, 55^{\circ} \mathrm{C}$ for $1 \mathrm{~min}$ and $72{ }^{\circ} \mathrm{C}$ for $1 \mathrm{~min}$ with a final extension step of $72{ }^{\circ} \mathrm{C}$ for $5 \mathrm{~min}$. The amplified products were cloned into pUC19 and sequenced with an ABI PRISM 310 Genetic Analyzer (Applied Biosystems). The partial 16S rRNA gene sequence (1465 bp), the partial mcrA gene sequence (470 bp) and the deduced McrA amino acid sequence (156 aa) were compared with those in the GenBank database using the BLAST program. Sequences of the novel isolate and those of closely related members retrieved from the database were aligned using CLUSTAL $\mathrm{w}$ (Thompson et al., 1994) and phylogenetic analysis was conducted using MEGA 4.0 software (Tamura et al., 2007). Phylogenetic trees based on 16S rRNA gene and deduced McrA amino acid sequences were constructed using the neighbour-joining method (Saitou \& Nei, 1987). Distances were computed using the maximum-composite-likelihood method (Tamura et al., 2004). For both phylogenetic trees, bootstrap values (Felsenstein, 1985) were obtained from 1000 random resamplings of the data.

Strain $169^{\mathrm{T}}$ was isolated from a propionate-oxidizing enrichment culture, originally obtained as an innoculant from rice-field soil. In this culture, large cell aggregates $(\sim 100 \mu \mathrm{m})$ consisted of autofluorescent methanogen-like cells; non-fluorescent cells were also frequently seen under the microscope. The autofluorescent cells were non-motile and straight or slightly curved rods with rounded ends, similar to other members of the genus Methanobacterium. An axenic culture of the apparently dominant methanogen was obtained by repeated application of the roll tube isolation procedure. The purity of the culture was examined in medium containing either $20 \mathrm{mM}$ sodium sulphate and $20 \mathrm{mM}$ lactate, $0.2 \%$ glucose and $0.1 \%$ polypeptone or $0.1 \%$ yeast extract. No growth was observed and no contaminants were detected microscopically, indicating a pure culture.

Cells of strain $169^{\mathrm{T}}$ were non-motile, Gram-reactionvariable, rod-shaped $(1.6-5.0 \times 0.35-0.5 \mu \mathrm{m})$ and usually occurred as single cells but sometimes formed long chains up to $30 \mu \mathrm{m}$. Negative staining preparations showed some fimbriae ( $5 \mathrm{~nm}$ in diameter) were present at both ends of the cell but no flagella were observed (Fig. 1a). The maximum number of fimbriae was $\sim 10$ per cell. Dark patches were seen distributed over the cell surface (Fig. 1b), similar to those seen in Methanobacterium formicicum DSM $1535^{\mathrm{T}}$; these represented intracytoplasmic membranous elements of unknown function (Langenberg et al., 1968). The fibrillar meshwork previously observed with $M$. formicicum strain MF (Langenberg et al., 1968) was not detected. Ultrathin sections showed a single-layered electron-dense cell wall about $6 \mathrm{~nm}$ thick, which is typical of Gram-positive bacteria (Fig. 1c). Strain $169^{\mathrm{T}}$ showed fluorescence under UV light (420 nm), typical of methanogens. Cells of strain $169^{\mathrm{T}}$ did not lyse in double-distilled water or $2 \%(\mathrm{w} / \mathrm{v})$ SDS after $90 \mathrm{~min}$. Colonies in deep agar medium were circular, white-cream in colour and $0.5 \mathrm{~mm}$ in diameter after 3 months of incubation. 


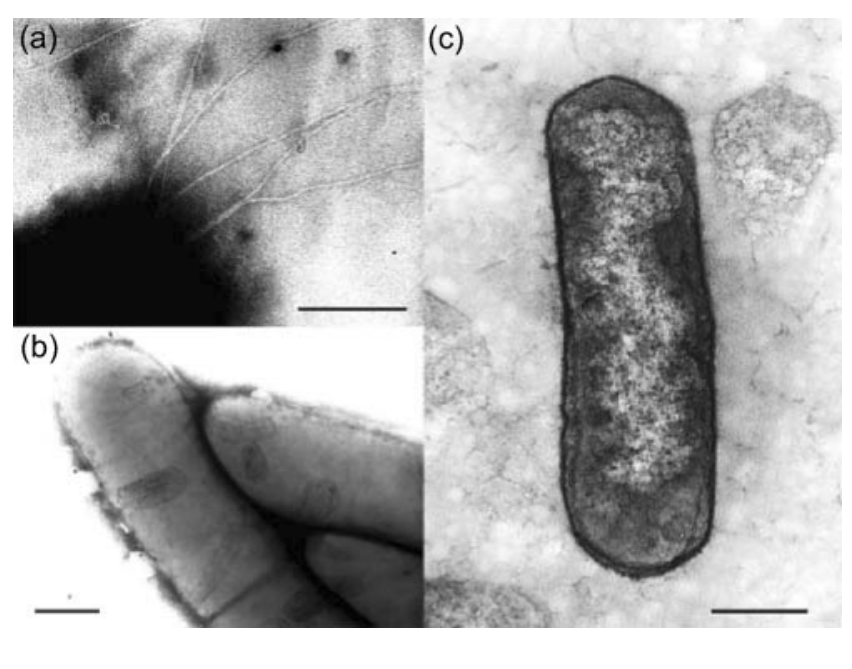

Fig. 1. Electron micrographs showing negatively stained cells of strain $169^{\top}(a, b)$ and a transmission electron micrograph of an ultrathin section of strain $169^{\top}$ (c). Bar, $200 \mathrm{~nm}$.

Growth and methane production were observed at 15$45{ }^{\circ} \mathrm{C}$ and the optimum temperature for growth was $40{ }^{\circ} \mathrm{C}$ (Fig. 2a). No growth was observed at $4{ }^{\circ} \mathrm{C}$ and $50{ }^{\circ} \mathrm{C}$. The $\mathrm{pH}$ range for growth was 6.5-9.6 (optimum $\mathrm{pH}$ 7.5-8.5) (Fig. 2b). No growth was observed below $\mathrm{pH} 6.0$ or above $\mathrm{pH}$ 9.9. The salinity range for growth was $0-70 \mathrm{~g} \mathrm{NaCl} \mathrm{l}^{-1}$ $(0-1.2 \mathrm{M})$ and optimum growth was observed at $5 \mathrm{~g} \mathrm{NaCl}$ $1^{-1}(0.086 \mathrm{M})$ (Fig. 2c). Growth and methane production were completely inhibited at $80 \mathrm{~g} \mathrm{NaCl} \mathrm{l}^{-1}(1.37 \mathrm{M})$. Doubling time was $21 \mathrm{~h}$ under optimal conditions $(\mathrm{pH} 8.5$, $40{ }^{\circ} \mathrm{C}$ ). Strain $169^{\mathrm{T}}$ grew only on hydrogen/carbon dioxide as sole carbon and energy sources. No growth factors or vitamins were required for growth. Addition of glucose $(0.1 \%)$, acetate $(2 \mathrm{mM})$, tryptone $(0.1 \%)$, polypeptone $(0.1 \%)$, Casamino acids $(0.1 \%)$, cysteine-hydrochloride $(0.025 \%)$, trypticase peptone $(0.1 \%)$ and yeast extract $(0.1 \%)$ did not stimulate methane production. Methane production was reduced in medium containing $20 \mathrm{mM}$ sodium formate (about $35 \%$ of that produced by the control). The DNA G $+\mathrm{C}$ content of strain $169^{\mathrm{T}}$ was $39.3 \mathrm{~mol} \%$.
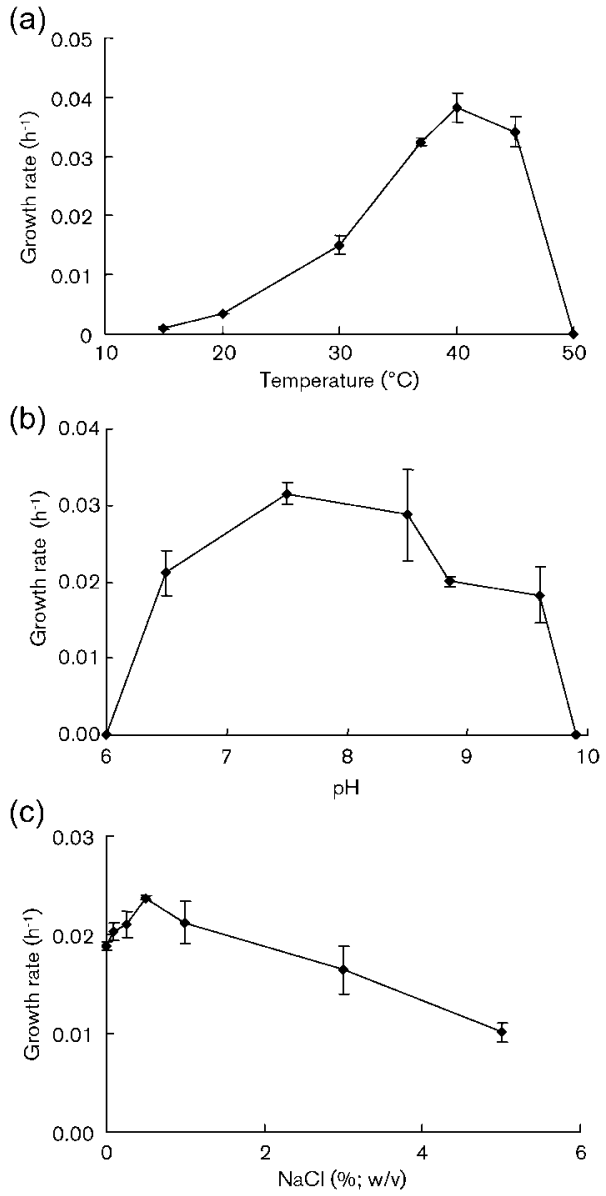

Fig. 2. Growth rates of strain $169^{\top}$ under different temperatures (a), $\mathrm{pH}$ levels (b) and $\mathrm{NaCl}$ concentrations (c). The effect of $\mathrm{pH}$ on growth (b) was tested under an atmosphere of $\mathrm{H}_{2} / \mathrm{CO}_{2}$ (90:10, $\mathrm{v} / \mathrm{v}$ ) at atmospheric pressure. As strain $169^{\top}$ grew very slowly at around $7 \% \mathrm{NaCl}$ (c), the specific growth rate could not be calculated over the test period of 4 weeks. Specific growth rates are plotted. Data points represent the means of triplicate experiments and error bars represent SE.

Growth of strain $169^{\mathrm{T}}$ was not inhibited by $\left(\mathrm{mg} \mathrm{l^{-1 }}\right)$ ampicillin (2000), vancomycin (2000) or penicillin (1000) but the addition of penicillin (2000), nalidixic acid (100)

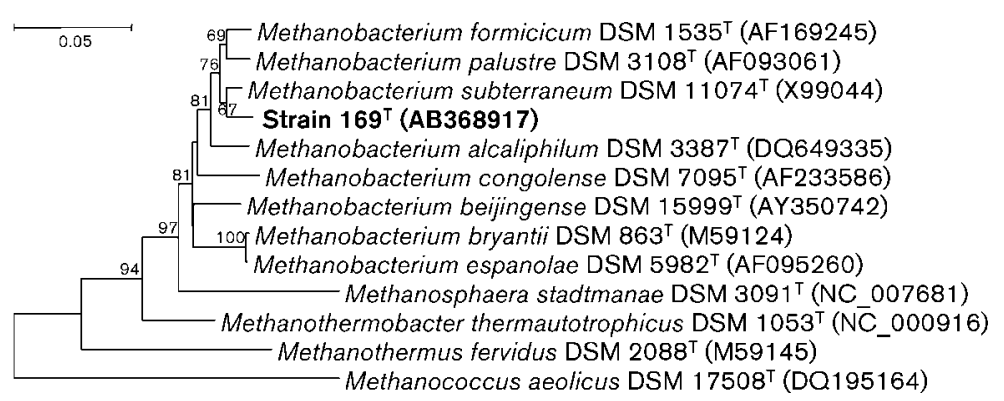

http://ijs.sgmjournals.org
Fig. 3. Phylogenetic tree based on $16 \mathrm{~S}$ rRNA gene sequences, indicating the relationship of strain $169^{\top}$ to other methanogenic archaea. The tree was constructed using the neighbourjoining method. Methanothermobacter thermoautotrophicus DSM $1053^{\top}$ was used as an outgroup. Bootstrap values $>50 \%$, based on 1000 resamplings, are shown at branch points. Accession numbers are given in parentheses. Bar, 0.01 substitutions per nucleotide position. 


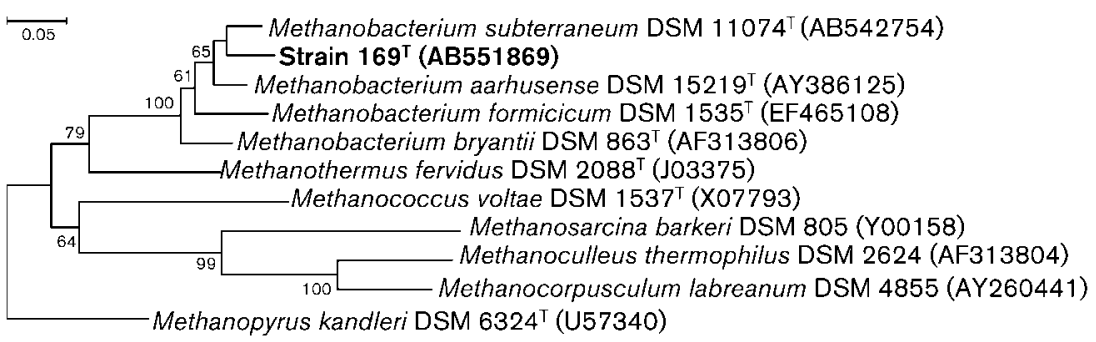

Fig. 4. Phylogenetic tree based on deduced McrA amino acid sequences, indicating the relationships between strain $169^{\top}$ and other methanogenic archaea. The tree was reconstructed based on a distance matrix of 147 amino acid positions using PAM distance correction. Methanopyrus kandleri DSM $6324^{\top}$ was used as an outgroup. Bootstrap values $>50 \%$, based on 1000 resamplings, are shown at branch points. Accession numbers are given in parentheses. Bar, 0.05 substitutions per nucleotide position. and streptomycin (100) decreased growth rate to $61.0 \%$, $53.8 \%$ and $52.1 \%$, respectively, when compared to the control. These antibiotics caused greater reductions in growth rates at higher concentrations. Growth of strain $169^{\mathrm{T}}$ was also inhibited by the addition of $\left(\mathrm{mg} \mathrm{l}^{-1}\right)$ nalidixic acid (1000), neomycin (100), bacitracin (100) and chloramphenicol (100). As an archaeon, strain $169^{\mathrm{T}}$ should not be susceptible to certain antibiotics effective against bacteria (streptomycin, nalidixic acid, neomycin, bacitracin and chloramphenicol). However, Methanobacterium subterraneum DSM $11074^{\mathrm{T}}$ was also sensitive to chloramphenicol (40) and bacitracin (40) (Kotelnikova et al., 1998) but not nalidixic acid (100) or streptomycin (100) (Kotelnikova et al., 1998).

The almost full-length 16S rRNA gene sequence of strain $169^{\mathrm{T}}$ (1465 bp) was amplified and sequenced. A phylogenetic tree was constructed based on the sequences of the isolate and those of closely related species (Fig. 3). The phylogenetic tree showed that a mesophilic group of species of the genus Methanobacterium were the most closely related species to strain $169^{\mathrm{T}}$. The highest levels of $16 \mathrm{~S}$ rRNA gene sequence similarity to strain $169^{\mathrm{T}}$ were observed with M. subterraneum DSM $11074^{\mathrm{T}}(96.8 \%)$ and Methanobacterium formicicum DSM $1535^{\mathrm{T}}$ (96.4\%). The partial sequence (470 bp) of the mcrA gene of strain $169^{\mathrm{T}}$ was also determined and a phylogenetic tree based on the deduced amino acid sequence of morA genes was constructed (Fig. 4). This tree also supported the position of strain $169^{\mathrm{T}}$ within the genus Methanobacterium. The closest relatives to strain $169^{\mathrm{T}}$ based on the $m c r A$ gene and deduced amino acid sequences were M. subterraneum DSM $11074^{\mathrm{T}}(93.3 \%$ amino acid sequence identity, $86.6 \%$ nucleic acid sequence similarity) and Methanobacterium aarhusense DSM $15219^{\mathrm{T}}(93.3 \%$ amino acid sequence identity, $83.5 \%$ nucleic acid sequence similarity).

$16 \mathrm{~S}$ rRNA gene sequence analysis showed that strain $169^{\mathrm{T}}$ was related to known species of the genus Methanobacterium (Fig. 3). Based on its phenotypic

Table 1. Morphological and physiological characteristics of strain $169^{\top}$ and closely related species of the genus Methanobacterium

Taxa: 1, strain $169^{\mathrm{T}}$ (data from this study); 2, M. formicicum DSM $1535^{\mathrm{T}}$ (Bryant \& Boone, 1987); 3, M. subterraneum DSM $11074^{\mathrm{T}}$ (Kotelnikova et al., 1998); 4, M. alcaliphilum DSM 3387 ${ }^{\mathrm{T}}$ (Worakit et al., 1986); 5, M. palustre DSM 3108 ${ }^{\mathrm{T}}$ (Zellner et al., 1989). All strains utilize hydrogen/ carbon dioxide as sources of energy and carbon. -, Negative; +, positive; v, variable; A, acetate; YE, yeast extract; P, peptone; ND, not determined.

\begin{tabular}{|c|c|c|c|c|c|}
\hline Characteristic & 1 & 2 & 3 & 4 & 5 \\
\hline \multirow[t]{2}{*}{ Size $(\mu \mathrm{m})$} & $0.35-0.5$ & $0.4-0.8$ & $0.1-0.15$ & $0.5-0.6$ & 0.5 \\
\hline & $\times 1.6-5$ & $\times 2-15$ & $\times 0.6-1.2$ & $\times 2-25$ & $\times 2.5-5$ \\
\hline Long rods & + & + & - & + & + \\
\hline Filaments & + & + & - & + & + \\
\hline Fimbriae & + & + & ND & $\mathrm{ND}$ & ND \\
\hline Gram reaction & $\mathrm{V}$ & $\mathrm{v}$ & + & - & + \\
\hline Formate utilization & - & + & + & - & + \\
\hline Chemoautotrophic & + & + & + & - & + \\
\hline Growth stimulation by other compounds & - & A & - & YE, $\mathrm{P}$ & ND \\
\hline $\mathrm{pH}$ range for growth (optimum) & $6.5-9.6(7.5-8.5)$ & $6.6-7.8(\mathrm{ND})$ & $6.5-9.2(7.8-8.8)$ & $7.0-9.9(8.1-9.1)$ & $\mathrm{ND}(7)$ \\
\hline $\begin{array}{l}\text { Temperature range for growth }\left({ }^{\circ} \mathrm{C}\right) \\
\text { (optimum) }\end{array}$ & $15-45(40)$ & $25-50(37-45)$ & $3.6-45(20-40)$ & ND (37) & $20-45(33-37)$ \\
\hline Tolerance of $\mathrm{NaCl}(\mathrm{M})$ (optimum) & $0-1.2(0.086)$ & ND & $0-1.4(0.2-1.25)$ & ND & $0-0.3(0.2)$ \\
\hline DNA G $+\mathrm{C}$ content $(\mathrm{mol} \%)$ & 39.3 & $41-42$ & 54.5 & 57 & 34 \\
\hline
\end{tabular}


characteristics, strain $169^{\mathrm{T}}$ could be distinguished from phylogenetically related taxa, as shown in Table 1. Closely related species $M$. formicicum and M. subterraneum used formate as a methanogenic substrate, whereas strain $169^{\mathrm{T}}$ grew only on hydrogen/carbon dioxide as sole energy and carbon sources. Growth of M. formicicum was stimulated by acetate but growth of strain $169^{\mathrm{T}}$ was not. The DNA G $+\mathrm{C}$ content of strain $169^{\mathrm{T}}$ was $39.3 \mathrm{~mol} \%$, while that of $M$. subterraneum was $54.5 \mathrm{~mol} \% \mathrm{G}+\mathrm{C}$. Susceptibility to antibiotics (100 mg streptomycin $\mathrm{l}^{-1}$ and $500 \mathrm{mg}$ nalidixic acid $1^{-1}$ ) also differed between strain $169^{\mathrm{T}}$ and M. subterraneum.

Based on its morphological, physiological and phylogenetic characteristics, strain $169^{\mathrm{T}}$ represents a novel species of the genus Methanobacterium, for which the name Methanobacterium kanagiense sp. nov. is proposed.

\section{Description of Methanobacterium kanagiense sp. nov.}

Methanobacterium kanagiense (ka.na.gi.en'se. N.L. n. adj. kanagiense pertaining to Kanagi, Aomori, Japan, where the organism was isolated).

Cells are non-motile, Gram-reaction-variable and rodshaped $(1.6-5.0 \times 0.35-0.5 \mu \mathrm{m})$. Hydrogen/carbon dioxide are the only substrates that support growth. Formate, methylamines, acetate, pyruvate, methanol and other alcohols plus carbon dioxide are not utilized. Grows autotrophically in mineral medium without any organic additives. Growth is not stimulated by acetate or yeast extract. Vitamins are not essential for growth. Grows at 15$45^{\circ} \mathrm{C}$, at $\mathrm{pH}$ 6.5-9.6, and with $0-70 \mathrm{~g} \mathrm{NaCl} 1^{-1}$.

The type strain, $169^{\mathrm{T}}\left(\mathrm{DSM} 22026^{\mathrm{T}}=\mathrm{JCM} 15797^{\mathrm{T}}\right)$, was isolated from an anaerobic, propionate-oxidizing enrichment culture derived from rice-field soil. The DNA G $+\mathrm{C}$ content of the type strain is $39.3 \mathrm{~mol} \%$ (as determined by HPLC).

\section{Acknowledgements}

The authors gratefully acknowledge the kind contribution of $\mathrm{Dr}$ Nakamura (Gifu University, Japan) in providing the recombinant enzyme (rPeiW). This work was performed in part at the Gene Research Center, Hirosaki University, Japan.

\section{References}

Asakawa, S., Morii, H., Akagawa-Matsushita, M., Koga, Y. \& Hayano, K. (1993). Characterization of Methanobrevibacter arboriphilicus SA isolated from a paddy field soil and DNA-DNA hybridization among M. arboriphilicus strains. Int J Syst Bacteriol 43, 683-686.

Asakawa, S., Akagawa-Matsushita, M., Morii, H., Koga, Y. \& Hayano, K. (1995). Characterization of Methanosarcina mazei TMA isolated from a paddy field soil. Curr Microbiol 31, 34-38.

Bartholomew, J. W. \& Mittwer, T. (1952). The Gram stain. Bacteriol Rev 16, 1-29.

Boone, D. R., Whitman, W. B. \& Rouvière, P. (1993). Diversity and taxonomy of methanogens. In Methanogenesis. Ecology, Physiology,
Biochemistry and Genetics, pp. 35-80. Edited by J. G. Ferry. New York: Chapman \& Hall.

Bryant, M. P. \& Boone, D. R. (1987). Isolation and characterization of Methanobacterium formicicum MF. Int J Syst Bacteriol 37, 171.

Cicerone, R. J. \& Oremland, R. S. (1988). Biogeochemical aspects of atmospheric methane. Global Biogeochem Cycles 2, 299-327.

Conrad, R., Bak, F., Seitz, H. J., Thebrath, B., Mayer, H. P. \& Schütz, H. (1989a). Hydrogen turnover by psychrophilic homoacetogenic and mesophilic methanogenic bacteria in anoxic paddy soil and lake sediment. FEMS Microbiol Ecol 62, 285-294.

Conrad, R., Mayer, H. P. \& Wüst, M. (1989b). Temporal change of gas metabolism by hydrogen-syntrophic methanogenic bacterial associations in anoxic paddy soil. FEMS Microbiol Lett 62, 265-273.

Dong, X. \& Stams, A. J. M. (1995). Evidence for $\mathrm{H}_{2}$ and formate formation during syntrophic butyrate and propionate degradation. Anaerobe 1, 35-39.

Felsenstein, J. (1985). Confidence limits on phylogenies: an approach using the bootstrap. Evolution 39, 783-791.

Fetzer, S., Bak, F. \& Conrad, R. (1993). Sensitivity of methanogenic bacteria from paddy soil to oxygen and desiccation. FEMS Microbiol Ecol 12, 107-115.

Galchenko, V. F., Lein, A. \& Ivanov, M. (1989). Biological sinks of methane. In Exchange of Trace Gases Between Terrestrial Ecosystems and the Atmosphere, pp. 59-71. Edited by M. O. Andreae \& D. S. Schimel. Chichester: John Wiley and Sons.

Garcia, J. L. (1990). Taxonomy and ecology of methanogens. FEMS Microbiol Rev 87, 297-308.

Großkopf, R., Janssen, P. H. \& Liesack, W. (1998). Diversity and structure of the methanogenic community in anoxic rice paddy soil microcosms as examined by cultivation and direct $16 \mathrm{~S}$ rRNA gene sequence retrieval. Appl Environ Microbiol 64, 960-969.

Hungate, R. E. (1969). A roll tube method for cultivation of strict anaerobes. Methods Microbiol 3, 117-132.

Joulian, C., Ollivier, B., Patel, B. K. C. \& Roger, P. A. (1998). Phenotypic and phylogenetic characterization of dominant culturable methanogens isolated from ricefield soils. FEMS Microbiol Ecol 25, 135-145.

Kellenberger, E., Ryter, A. \& Sechaud, J. (1958). Electron microscope study of DNA-containing plasms. II. Vegetative and mature phage DNA as compared with normal bacterial nucleoids in different physiological states. J Biophys Biochem Cytol 4, 671-678.

Kotelnikova, S., Macario, A. J. L. \& Pedersen, K. (1998). Methanobacterium subterraneum sp. nov., a new alkaliphilic, eurythermic and halotolerant methanogen isolated from deep granitic groundwater. Int J Syst Bacteriol 48, 357-367.

Langenberg, K. F., Bryant, M. P. \& Wolfe, R. S. (1968). Hydrogenoxidizing methane bacteria. II. Electron microscopy. J Bacteriol 95, 1124-1129.

Luton, P. E., Wayne, J. M., Sharp, R. J. \& Riley, P. W. (2002). The $m c r A$ gene as an alternative to $16 \mathrm{~S}$ rRNA in the phylogenetic analysis of methanogen populations in landfill. Microbiology 148, 3521-3530.

Mah, R. A. \& Smith, M. R. (1981). The methanogenic bacteria. In The Prokaryotes, vol. 1, pp. 948-977. Edited by M. P. Starr, H. Stolp, H. G. Trüper, A. Balows \& H. G. Schlegel. Berlin: Springer.

Nakamura, K., Terada, T., Sekiguchi, Y., Shinzato, N., Meng, X.-Y., Enoki, M. \& Kamagata, Y. (2006). Application of pseudomurein endoisopeptidase to fluorescence in situ hybridization of methanogens within the family Methanobacteriaceae. Appl Environ Microbiol 72, 6907-6913.

Oyaizu, H. S. \& Hiraishi, A. (1999). Molecular phylogenetic evolution. In Microbiology Experiment Methods, pp. 234-249. Edited by J. T. Sugiyama, 
M. Watanabe, K. I. Ohwada, T. Y. Kuroiwa, H. O. Yakahashi \& H. Tokuda. Japan: Koudansha Scientific.

Prinn, R. G. (1994). Global atmospheric-biospheric chemistry. In Global atmospheric-biospheric chemistry, pp. 1-18. Edited by R. G. Prinn. New York: Plenum.

Raimbault, M. (1981). [Inhibition de la formation de méthane par l'acétylène chez Methanosarcina barkeri]. Cah ORSTOM Ser Biol 43, 45-51 (in French).

Rajagopal, B. S., Belay, N. \& Daniels, L. (1988). Isolation and characterization of methanogenic bacteria from rice paddies. FEMS Microbiol Ecol 53, 153-158.

Saitou, N. \& Nei, M. (1987). The neighbor-joining method: a new method for reconstructing phylogenetic trees. Mol Biol Evol 4, 406425.

Sakai, S., Imachi, H., Hanada, S., Ohashi, A., Harada, H. \& Kamagata, Y. (2008). Methanocella paludicola gen. nov., sp. nov., a methane-producing archaeon, the first isolate of the lineage 'Rice Cluster I', and proposal of the new archaeal order Methanocellales ord. nov. Int J Syst Evol Microbiol 58, 929-936.

Schink, B. (1992). Syntrophism among prokaryotes. In The Prokaryotes, 2nd edn, pp. 276-299. Edited by A. Balows, H. G. Trüper, M. Dworkin, W. Harder \& K.-H. Schleifer. New York: Springer.

Stams, A. J. M. (1994). Metabolic interactions between anaerobic bacteria in methanogenic environments. Antonie van Leeuwenhoek 66, 271-294.
Takai, Y. (1970). The mechanism of methane fermentation in flooded paddy soil. Soil Sci Plant Nutr 16, 238-244.

Tamura, K., Nei, M. \& Kumar, S. (2004). Prospects for inferring very large phylogenies by using the neighbor-joining method. Proc Natl Acad Sci U S A 101, 11030-11035.

Tamura, K., Dudley, J., Nei, M. \& Kumar, S. (2007). MEGA4: molecular evolutionary genetics analysis (MEGA) software version 4.0. Mol Biol Evol 24, 1596-1599.

Thompson, J. D., Higgins, D. G. \& Gibson, T. J. (1994). CLUSTAL W: improving the sensitivity of progressive multiple sequence alignment through sequence weighting, position-specific gap penalties and weight matrix choice. Nucleic Acids Res 22, 4673-4680.

Widdel, F. \& Pfennig, N. (1981). Studies on dissimilatory sulfatereducing bacteria that decompose fatty acids. I. Isolation of new sulfate-reducing bacteria enriched with acetate from saline environments. Description of Desulfobacter postgatei gen. nov., sp. nov. Arch Microbiol 129, 395-400.

Worakit, S., Boone, D. R., Mah, R. A., Abdel-Samie, M.-E. \& ElHalwagi, M. M. (1986). Methanobacterium alcaliphilum sp. nov., an $\mathrm{H}_{2}$-utilizing methanogen that grows at high $\mathrm{pH}$ values. Int $J$ Syst Bacteriol 36, 380-382.

Zellner, G., Bleicher, K., Braun, E., Kneifel, H., Tindall, B. J., Conway de Macario, E. \& Winter, J. (1989). Characterization of a new mesophilic, secondary alcohol-utilizing methanogen, Methanobacterium palustre spec. nov. from a peat bog. Arch Microbiol 151, 1-9. 